\title{
Identification of Nitric Oxide Responsive Genes in the Rudimentary Leaves of Litchi chinensis
}

\author{
Xingyu LU, Houbin CHEN, Zhiqun HU, Biyan ZHOU* \\ Guangdong Litchi Engineering Research Center, College of Horticulture, South China Agricultural University, 510642 Guangzhou, \\ China;786106910@qq.com; hbch@scau.edu.cn; zhqhu@scau.edu.cn; zhoubiyan@scau.edu.cn ("correspondingauthor)
}

\begin{abstract}
Litchi (Litchi chinensis Sonn.) is an evergreen woody fruit tree widely cultivated in subtropical and tropical regions. Warm winter and hot spring often leads to abnormal floral differentiation in litchi. Under this condition, the rudimentary leaves in the floral buds expand and the inflorescences will stop developing. Thus, how to promote abortion of rudimentary leaves in litchi inflorescence are important for floral development. Previous study indicated that nitric oxide (NO) produced by sodium nitroprusside (SNP) promoted flowering and abortion of rudimentary leaves in litchi. In the present study, a suppression subtractive hybridization (SSH) was used to identify NO responsive genes. As a result, 16 high homologous ESTs were obtained from the SSH library of the SNP treated rudimentary leaves. The ESTs were classified into three groups. They are disease/defensive, protein destination and storage, and protein synthesis. Quantitative reverse transcription PCR (qRT-PCR) analysis indicated that 6 out of the 7 randomly selected ESTs'expression showed an increasing trend from $0 \mathrm{~h}$ to $10 \mathrm{~h}$ of SNP treatment. It is suggested that the litchi homologs $18 \mathrm{~S}$ ribosomal RNA gene, cytochrome P450 like TBP, and the senescenceassociated protein, chaperone protein, and a hypothetical protein encoding genes may be involved in the NO-induced senescence in litchi rudimentary leaves. $L c E R D 15$-like may be a key gene involved in this process.
\end{abstract}

Keywords: abortion; nitric oxide; rudimentary leaves; suppression subtractive hybridization

\section{Introduction}

Litchi (Litchi chinensis) is an important subtropical fruit tree cultivated in Southeast Asia. Previous studies showed that low temperature is needed for floral initiation in litchi (Menzel and Simpson, 1988; Chen and Huang, 2005). However, abnormal warm winter and hot spring frequently happened in the past few decades, resulting in poor flowering in litchi. Litchi floral buds are mixed buds with apical or axillary panicle primordia, leaf primordia and rudimentary leaves (Huang and Chen, 2005). Under warm winter condition, the rudimentary leaves may expand quickly and the panicle primordia may cease to develop and shrink (Yang et al., 2017). Hence, warm winter turn to be a harsh challenge for litchi production. Control the growth of rudimentary leaves is important for litchi flowering.

Nitric oxide (NO) is an important signal molecule in plant cells (Beligni et al., 2001; Palavan-Unsal et al., 2009). Together with reactive oxygen species (ROS), NO accumulated under abiotic or biotic stress. $\mathrm{NO}$ and ROS are involved in programmed cell death (PCD) processes which are related with leaf abortion (Wang et al., 2013a, b).
Our previous studies showed that NO and ROS are involved in the low temperature-induced flowering and leaf abortion (Zhou et al., 2012). Further, we have identified many ROS responsive genes in floral bud and rudimentary leaves (Liu et al., 2013; Lu et al., 2014), as well as NO responsive genes in floral buds (Liu et al., 2015). In this study, we identified NO responsive genes in the rudimentary leaves by suppression subtractive hybridization (SSH), with the aim to provide basic materials for controlling the growth of rudimentary leaves and promoting flowering in litchi.

\section{Materials and Methods}

\section{Plant material and experiment procedures}

Sampling trees were grown at the experimental orchard of South China Agricultural University. Thirty-year-old litchi (Litchi chinensis Sonn. cv. Nuomici) trees grafted on the rootstock 'Huaizhi' were selected. About $6 \mathrm{~cm}$ length of branches with new flushes were cut off from the trees and immediately placed in water. The cuttings were treated with water or solutions containing $0.5 \mathrm{mM}$ sodium nitroprusside (SNP) (Sigma, USA) according to the method of Zhou et al. (2012). All the cuttings were placed in a growth chamber 
with $160 \mu \mathrm{mol} \mathrm{m} \mathrm{m}^{-2}$ photosynthetic photon flux density at $20{ }^{\circ} \mathrm{C}$. The third and the fourth of the rudimentary leaves (Fig. 1) were collected at $0 \mathrm{~h}, 5 \mathrm{~h}$ and $10 \mathrm{~h}$ of SNP treatment. The leaves were frozen in liquid nitrogen and stored at $-80{ }^{\circ} \mathrm{C}$ for construction of SSH library and quantitative reverse transcription PCR (qRT-PCR) analysis. The proximal angle $\alpha$, and the distal angle $\beta$ of the third rudimentary leaves as shown in Fig. 1 were measured according to the method of Lu et al. (2014). The angular dimension was measured by degree.

\section{Construction of suppression subtractive hybridization (SSH) cDNA library}

Total RNA was extracted from frozen leaves according the method of Zhou et al. (1999). RNA extracted from rudimentary leaves treated with water for $10 \mathrm{~h}$ was used as driver and those treated with SNP for $10 \mathrm{~h}$ was used as tester. PolyATract mRNA isolation system III (Promega, USA) was used to isolate mRNA from total RNA, and subtracted library was prepared using PCR-SelectTM cDNA subtraction kit (Clontech, USA) according to the manufacturer's instructions. After tester cDNA was digested with Rsa I and ligated to adaptors, two rounds of hybridization and PCR were run to enrich the differentially expressed fragments. The second-round PCR products of subtracted cDNA was cloned into pMD19-T Vector (TaKaRa, Japan) and then transformed into Escherichia coli $\mathrm{DH} 5 \alpha$. Positive transformants were selected on LB medium supplemented with $50 \mathrm{mg} \mathrm{L}^{-1}$ ampicillin, X-gal (5-bromo-4chloro-3-indolyl- $\beta$-D-galactopyranoside) and IPTG (isopropyl- $\beta$-D-thiogalactopyranoside).

\section{Identification of the insert fragments by colony PCR}

White clones were picked, and then inoculated into LB medium. PCR amplification was done using the bacterial suspension as template, the nested primer 1 and primer $2 \mathrm{R}$ as primers were provided by the PCR-SelectTM cDNA subtraction kit (Clontech, USA). PCR amplification by a

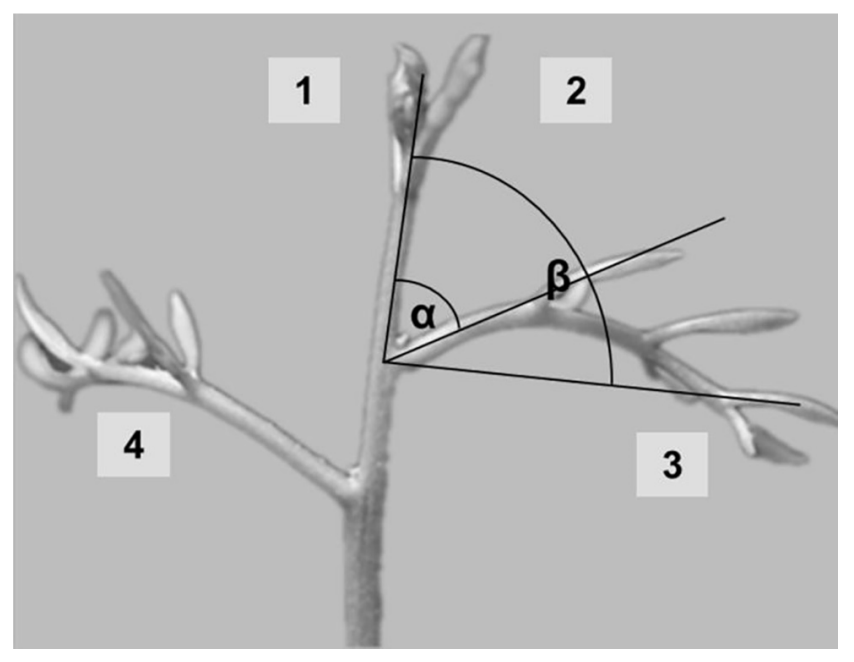

Fig. 1. Image of a new flush showing the first to forth rudimentary leaves. $\alpha$, proximal angle of the rudimentary leaves; $\beta$, distal angle of the rudimentary leaves; numbers from 1 to 4 indicate the first, the second, the third, and the fourth rudimentary leaves respectively thermal cycler (Bio-Rad, USA) were run as follows: $95^{\circ} \mathrm{C}$ for $5 \mathrm{~min}$, followed by 35 cycles of $94^{\circ} \mathrm{C}$ for $30 \mathrm{~s}, 55^{\circ} \mathrm{C}$ for $30 \mathrm{~s}$, and $72^{\circ} \mathrm{C}$ for $90 \mathrm{~s}$.

\section{Reverse Northern analysis for positive clone selection}

Reverse Northern blot was performed to screen positive clones. According to the manufacturer's instruction for DIG High Prime DNA labelling and detection starter kit II (Roche, Switzerland), two cDNA probes (driver and tester) were prepared using random primers and were labelled with digoxin (DIG). $4 \mu \mathrm{L}$ of colony PCR products were denatured at $100{ }^{\circ} \mathrm{C}$ for $5 \mathrm{~min}$ and quickly placed on ice for $5 \mathrm{~min}$, then mixed with $0.6 \mathrm{M} \mathrm{NaOH}$ respectively. Denatured DNA was blotted onto two nylon membranes (Roche, Switzerland). Saturated with 1.0 M Tris- $\mathrm{HCl}(\mathrm{pH}$ 7.5), the two membranes were placed on the chromatography paper, dried at room temperature and fixed at $80^{\circ} \mathrm{C}$ for $2 \mathrm{~h}$. The labeled 'tester' cDNA probe was hybridized to one membrane, and the labeled 'driver' probe to the other. After overnight hybridization and stringency washes, a chromogenic reaction was carried out. The hybridized membranes were exposed to X-ray film (Kodak XBT-1; $12.7 \mathrm{~cm}^{*} 17.8 \mathrm{~cm}$ ) for more than $30 \mathrm{~min}$ at $15-25^{\circ} \mathrm{C}$ after incubate for $10 \mathrm{~min}$ at $37^{\circ} \mathrm{C}$.

\section{DNA sequencing and analysis}

Differentially expressed clones confirmed by the reversed Northern blot were selected and sequenced by Majorbio Co., Ltd. (Shanghai, China).The sequences were analyzed using BLAST program (http:// www.ncbi.nlm.nih. gov/BLAST/) at NCBI. Functional classification of the clones was according to the method of Bevan et al. (1998).

\section{Analysis of EST expression by $q R T-P C R$}

Total RNA of the $0 \mathrm{~h}, 5 \mathrm{~h}$ and $10 \mathrm{~h}$ SNP-treated rudimentary leaves for qRT-PCR were extracted using kits from Huayueyang Biotechnology Co., Ltd. (Beijing, China), according to the manufacturer's protocol. First-strand cDNA was generated from $1 \mu \mathrm{g}$ total RNA using the superscript first-strand synthesis system (Invitrogen, USA). Primers for qRT-PCR were designed using Primer Premier 5.0 software (Premier, Canada) and synthesized by Sangon Biotech Co., Ltd. (Shanghai, China). All the primers are shown in Table 1. Litchi homologue actin (accession number HQ588865.1) was the reference gene. qPCR was performed on an iQ5 optical system (Bio-Rad, USA) using a SYBR Green based qPCR assay. Each reaction mixture was $20 \mu \mathrm{L}$ containing 6 $\mu \mathrm{L}$ of diluted first-strand cDNAs (40-80 ng) and $250 \mathrm{nM}$ primer, SYBR Green PCR Master Mix (TaKaRa, Japan) 10 $\mu \mathrm{L}$. The qPCRs were run as follows: $95^{\circ} \mathrm{C}$ for $10 \mathrm{~min}$, followed by 40 cycles of $95^{\circ} \mathrm{C}$ for $30 \mathrm{~s}, 56^{\circ} \mathrm{C}$ for $30 \mathrm{~s}$, and 72 ${ }^{\circ} \mathrm{C}$ for $30 \mathrm{~s}$ in 96-well optical reaction plates (Bio-Rad, USA). Each qRT-PCR analysis was performed in triplicate. Expression levels of the tested reference genes were determined by CT values and calculated by $2^{-} \triangle^{\mathrm{Ct}}$ (Livak and Schmittgen, 2001).

\section{Statistical analysis}

All data were subjected to analysis of variances using a SPSS program (SPSS Inc. Chicago, IL, USA). The differences among treatment means were evaluated by Duncan's multiple range test $(\mathrm{P} \leq 0.01)$. 
610

Table 1. Primer sequences of the reference gene and ESTs for qRT-PCR

\begin{tabular}{cccc}
\hline Clone & Description in NCBI database & Forward primer $\left(5^{\prime} \rightarrow 3^{\prime}\right)$ & Reverse primer $\left(5^{\prime} \rightarrow 3^{\prime}\right)$ \\
\hline & $\beta$ actin & AGTTTGGTTGATGTGGGAGAC & TGGCTGAACCCGAGATGAT \\
1008 & protein EARLY RESPONSIVE TO & TGGCTCCAGGAATGCTAC & ACATCGGCTTCTCAAACG \\
397 & DEHYDRATION 15-like & TGATAtive senescence-associated protein & AATACGAACCGTGAAAGC \\
372 & cytochrome P450 like_TBP & AAAGCATTGCGATGGTCC & CGTTCCCTTGGCTGTGGT \\
457 & vegetative storage protein & TGACCCTGTCGTAAATCC & GCTTCCGAGCCGTTGTAT \\
11 & 18S ribosomal RNA gene, partial sequence & CCGTTGCTCTGATGATTC & CTGCCTTCCTTGGATGTG \\
261 & Chaperone protein dnaj 10 & TACTCCAAGGTGCCAAAT & CAACTGAAACTGTCTACGATGA \\
987 & hypothetical protein GUITHDRAFT_79647 & AACATCTAAGGGCATCACA & GACCTCAGCCTGCTAACT \\
\hline
\end{tabular}

\section{Results}

\section{SNP induced abortion of rudimentary leaves}

Our previous work revealed an early sign of abortion of rudimentary leaves which was the downward growth of the leaves (Zhou et al., 2008). We also established method for measuring the degree of the downward growth by proximal angle and the distal angle (Lu et al., 2014). In this study, to confirm the effect of the SNP-generated NO on abortion of rudimentary leaves, shoot cuttings were treated with water or SNP in a growth chamber. Besides, our preliminary study confirmed that detached shoots could survive in water without wilting for at least $2 \mathrm{~d}$. The proximal angle $(\alpha)$ and the distal angle $(\beta)$ of the third leaves were measured (Fig. 1). The results showed that proximal angle $\alpha$ significantly increased at $5 \mathrm{~h}$ of SNP-treatment, and remained at similar level at $10 \mathrm{~h}$ of treatment. The distal angle $\beta$ continually increased during the whole stage of the treatment (Table 2). The SNP-treated rudimentary leaves showed epinasty as characterized by downward curvature of leaves (Fig. 2A, B, C), presenting an early sign of abortion (Zhou et al., 2008).
Differential screening of SSH library and functional classification of differentially expressed clones

Our SNP-treated SSH library was constructed for identifying $\mathrm{NO}$ responsive genes. To determine insert fragment size of the 1350 randomly picked clones, colonyPCRs were performed with the nested primers 1 and $2 \mathrm{R}$. We obtained 746 positive clones then, and the insertion fragments were $150-800 \mathrm{bp}$ (Fig. 3). Reverse northern blot was used to screen the differentially expressed EST clones. Finally, 180 clones that showed a differentially expressed pattern were obtained (Fig. 4). Their DNAs were subjected to sequencing. The results showed that the 180 clones were only ligated to 16 high homologous ESTs attributed to the high presenting times of the clones. As shown in Table 3, 7 of them were presented more than 5 times. Clone 987 encoding hypothetical protein GUITHDRAFT_79647 and clone 1008 encoding early responsive to dehydration 15-like (ERD15-like) protein were presented more than 40 times. According to the method of Bevan et al. (1998), 5 ESTs were classified to disease/defensive group, 3 ESTs were found to be related to protein destination and storage, and 3 ESTs were identified as protein synthesis (Table 4).

Table 2. Effects of SNP on angles of the rudimentary leaves

\begin{tabular}{ccc}
\hline Time of treatment & Proximal angle $\alpha\left(^{\circ}\right)$ & Distal angle $\beta\left(^{\circ}\right)$ \\
\hline $0 \mathrm{~h}$ & $53.80 \pm 1.28 \mathrm{~b}$ & $81.56 \pm 2.06 \mathrm{c}$ \\
$5 \mathrm{~h}$ & $58.20 \pm 1.26 \mathrm{a}$ & $112.17 \pm 2.72 \mathrm{~b}$ \\
$10 \mathrm{~h}$ & $59.83 \pm 1.78 \mathrm{a}$ & $122.33 \pm 2.65 \mathrm{a}$ \\
\hline
\end{tabular}

Notes: Values are means \pm SE from 30 rudimentary leaves. The differences among all the treatment means were evaluated by Duncan' $s$ multiple range tests at a 0.01 probability level using a SPSS program. Different lower-case letters indicate significant differences.
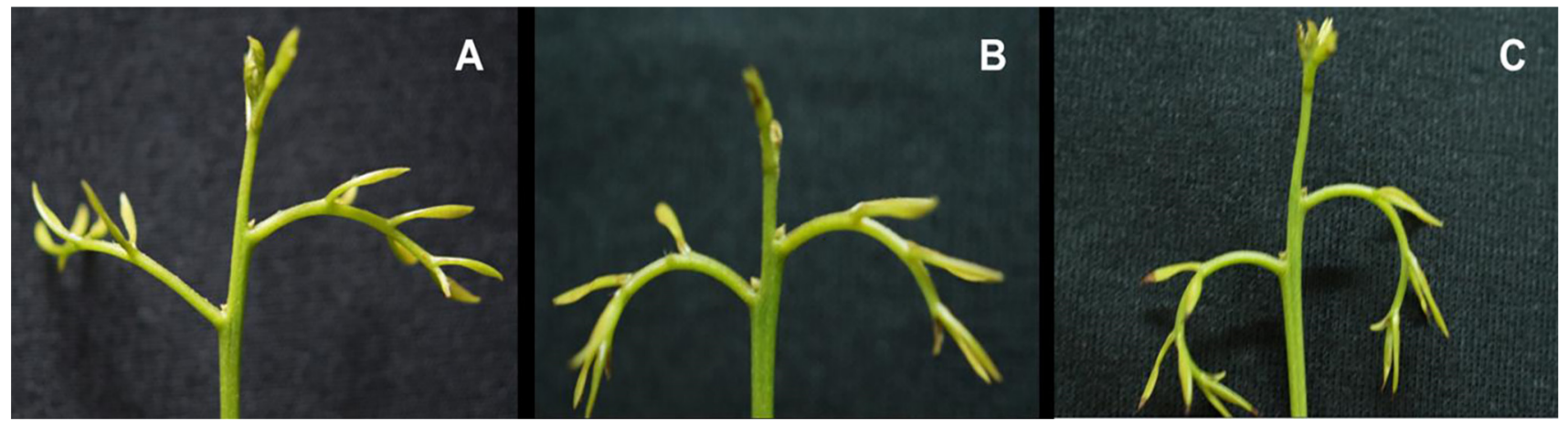

Fig. 2. Images of the new flushes. (A) Image of a new flush in $0 \mathrm{~h}$ of SNP treatment, (B) Image of a new flush in $5 \mathrm{~h}$ of SNP treatment, (C) Image of a new flush in $10 \mathrm{~h}$ of SNP treatment 


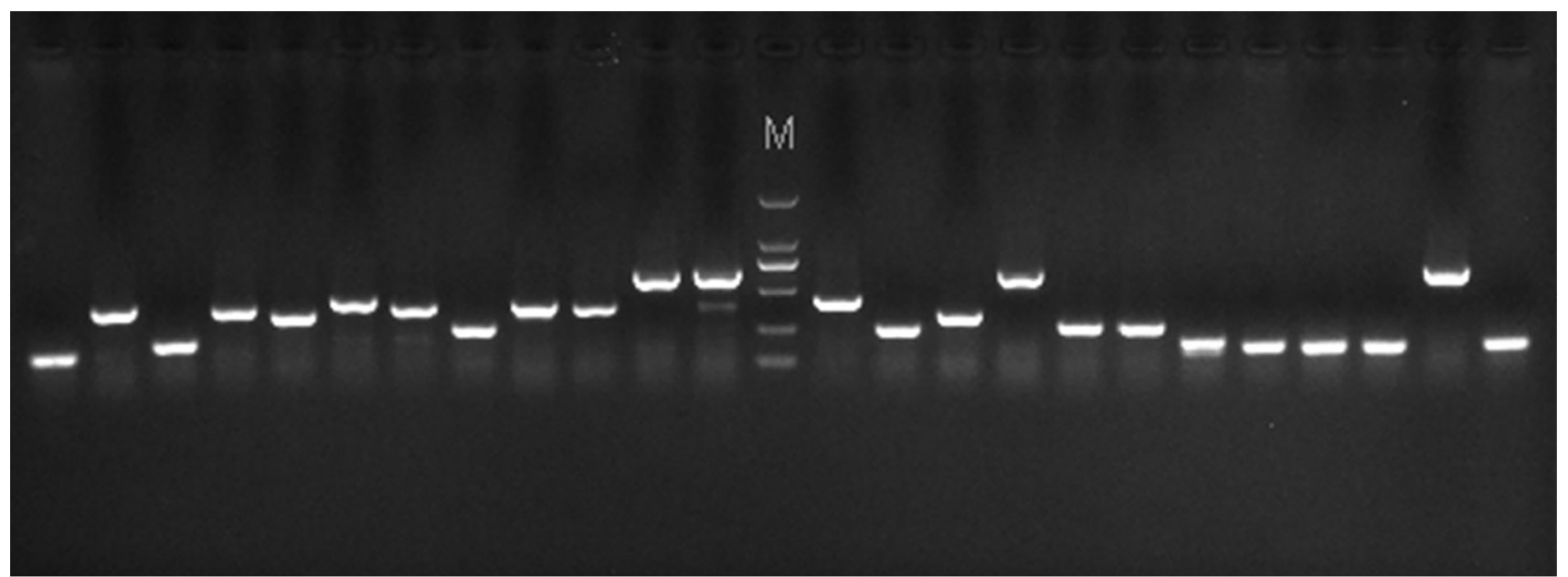

Fig. 3. PCR identification of the insert size in randomly selected clones from the SSH cDNA library. M, DNA marker 2000

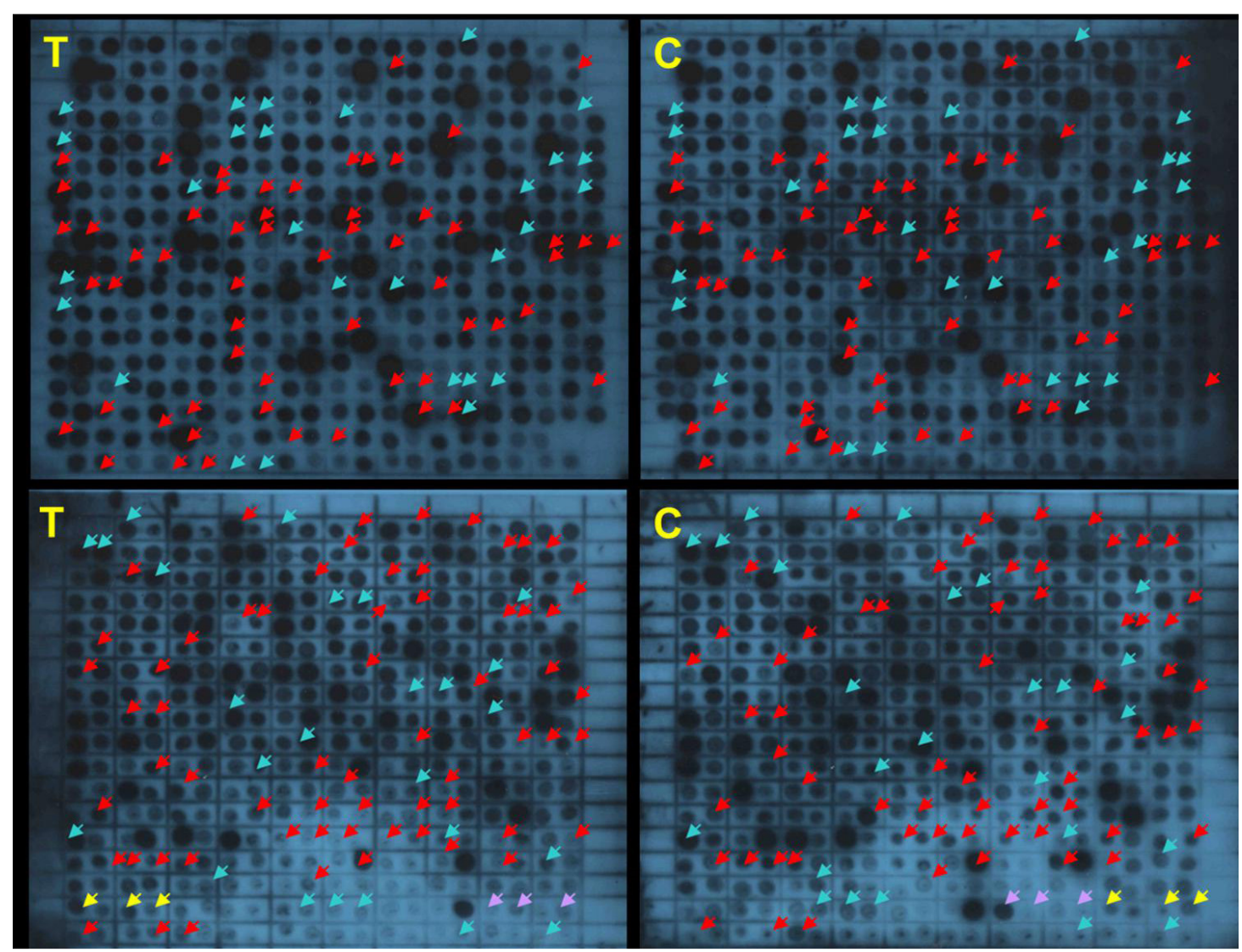

Fig. 4. Differential screening the SSH library by a reverse Northern analysis. Arrays of 746 clones were hybridized with DIG labeled tester $(\mathrm{T})$ and driver $(\mathrm{C})$. The spots marked with color arrows were recognized as differentially expressed clones

Table 3. Differentially expressed cDNA clones represented multiple times in SSH library

\begin{tabular}{cccc}
\hline Code & Similarity & Number of isolates & Functional classification \\
\hline 987 & hypothetical protein GUITHDRAFT_79647 & 48 & Unclear classification or unclassified \\
\hline 1008 & protein EARLY RESPONSIVE TO DEHYDRATION 15-like & 43 & Disease/Defence \\
247 & PREDICTED: transcription factor HBP-1b(c38) & 23 & Transcription \\
372 & cytochrome P450 like_TBP & 20 & Secondary metabolism \\
92 & 26S ribosomal RNA gene & 19 & Protein synthesis \\
457 & vegetative storage protein & 6 & Protein destination and storage \\
11 & 18 ribosomal RNA gene, partial sequence & 5 & Protein synthesis \\
\hline
\end{tabular}


612

Table 4.16 differentially expressed cDNA clones of SNP-treated SSH library in litchi

\begin{tabular}{|c|c|c|c|c|}
\hline Code & Accession & Description in NCBI database & E-value & Functional classification \\
\hline 1008 & XP_015877468.1 & $\begin{array}{c}\text { protein EARLY RESPONSIVE TO DEHYDRATION } \\
\text { 15-like (Ziziphus jujuba) }\end{array}$ & 5.00E-08 & Disease/Defence \\
\hline $\mathrm{C} 16$ & XP_013442968.1 & senescence-associated protein (Medicago truncatula) & $2.00 \mathrm{E}-52$ & Disease/Defence \\
\hline 397 & ABO20851.1 & putative senescence-associated protein (Lilium longiflorum) & $1.00 \mathrm{E}-56$ & Disease/Defence \\
\hline 468 & BAB33421.1 & putative senescence-associated protein (Pisum sativum) & $2.00 \mathrm{E}-15$ & Disease/Defence \\
\hline B15 & AHF81484.1 & small GTP Rab5 (Mangifera indica) & $4.00 \mathrm{E}-38$ & Disease/Defence \\
\hline 261 & XP_002512946.1 & chaperone protein dnaJ 10 (Ricinus communis) & $3.00 \mathrm{E}-04$ & Protein destination and storage \\
\hline 1220 & XP_002884233.1 & expressed protein (Arabidopsis lyrata subsp. lyrata) & $3.00 \mathrm{E}-12$ & Protein destination and storage \\
\hline 457 & ABG47463.1 & vegetative storage protein (Litchi chinensis) & $9.00 \mathrm{E}-25$ & Protein destination and storage \\
\hline 11 & JF759906.1 & $18 \mathrm{~S}$ ribosomal RNA gene, partial sequence (Litchi chinensis) & $0.00 \mathrm{E}+00$ & Protein synthesis \\
\hline 92 & AF479111.1 & 26S ribosomal RNA gene (Loeseneriella barbata) & $2.00 \mathrm{E}-112$ & Protein synthesis \\
\hline 65 & HM135404.1 & 26 ribosomal RNA gene, partial sequence (Citrus unshiu) & $9.00 \mathrm{E}-29$ & Protein synthesis \\
\hline 372 & BAA10929.1 & cytochrome P450 like_TBP (Nicotiana tabacum) & $2.00 \mathrm{E}-45$ & Secondary metabolism \\
\hline 247 & XP_002532112.1 & $\begin{array}{l}\text { PREDICTED: transcription factor HBP-1b(c38) } \\
\text { (Ricinus communis) }\end{array}$ & 2.00E-07 & Transcription \\
\hline 41 & XP_010044420.1 & $\begin{array}{l}\text { PREDICTED: mechanosensitive ion channel protein 6-like } \\
\text { (Eucalyptus grandis) }\end{array}$ & $3.00 \mathrm{E}-69$ & Transporters \\
\hline 849 & ACR56615.1 & plasma intrinsic protein 2;5 (Eucalyptus grandis) & $1.00 \mathrm{E}-21$ & Cell structure \\
\hline 987 & XP_005822623.1 & $\begin{array}{l}\text { hypothetical protein GUITHDRAFT_79647 } \\
\text { (Guillardia theta CCMP2712) }\end{array}$ & $9.00 \mathrm{E}-27$ & $\begin{array}{l}\text { Unclear classification or } \\
\text { unclassified }\end{array}$ \\
\hline
\end{tabular}

Expression analysis of 7 ESTs in rudimentary leaves

Based on the SSH results, we randomly selected 7 differentially expressed ESTs to determine their expression by qRT-PCR. They encode ERD15-like protein, senescence-associated protein, cytochrome P450 like TBP, vegetative storage protein, $18 \mathrm{~S}$ ribosomal RNA, chaperone protein and a hypothetical protein, respectively. Six out of the 7 ESTs showed increasing trends during 0 to $10 \mathrm{~h}$ of NO treatment (Fig. 5). For example, the expression level of which encoding ERD 15-like protein increased almost 20fold from $0 \mathrm{~h}$ to $10 \mathrm{~h}$ of treatment.

\section{Discussion}

$\mathrm{NO}$ is an important plant signal molecule. The NO responsive genes were reported to be associated with stressresponse, oxidation-reduction, signal transduction, senescence, reactive oxygen metabolism, and biological processes (Polverari et al., 2003; Lindermayr et al., 2005; Besson-Bard et al., 2009). Our previous study indicated that NO generated by SNP can promote flowering and rudimentary leaf abortion in litchi (Zhou et al., 2012). In addition, we have identified NO responsive genes in the floral buds by an SSH technique (Liu et al., 2015). In this study, we constructed an SSH cDNA library of the NOtreated rudimentary leaves to identify $\mathrm{NO}$ responsive genes. We obtained 16 high homologous ESTs from the SSH library. They are mainly related with the function of disease/defensive, protein destination and storage, and protein synthesis, suggested that these processes might be involved in the NO-induced abortion in litchi rudimentary leaves. Interestingly, we found that some identified ESTs had high presented times, such as the clone 987 encoding a hypothetical protein, and clone 1008 encoding ERD15 protein. The high presented times suggested that they might be the key genes involved in the NO-induced abortion of the rudimentary leaves.

ERDs are rapidly activated proteins under dehydration stress and could be classified into 16 groups (Kiyosue et al., 1994; Alves et al., 2011a), such as the chloroplast ATPdependent protease (ERD1), heat shock protein (ERD2,8), S-adenosyl-methionine-dependent methyltransferases (ERD3), membrane protein (ERD4), proline dehydrogenase (ERD5), hydrophilic protein (ERD15). Each kind of ERD gene has specific functions. In our SSH library, we isolated one EST encoding ERD15-like and the expression level of which increased almost 20-fold from $0 \mathrm{~h}$ to $10 \mathrm{~h}$ of SNP treatment, indicating that ERD15-like might be an important NO responsive gene involved in rudimentary leaf abortion.

ERD15 is a transcription factor that integrates several stress signaling pathways, such as abscisic acid (ABA) response, salicylic acid (SA)-dependent defense, mechanical and biological damage (Alves et al., 2011a). In Arabidopsis, the expression of ERD15 is up-regulated under stress conditions. ERD15 transgenic plants displayed hypersensitivity to ABA and enhanced tolerance to both drought and freezing (Kariola et al., 2006). In soybean, ERD15 functions as an upstream component of stress, and could connect endoplasmic reticulum stress with an osmotic stress-induced cell death signal (Alves et al., 2011b). In tomato, ERD15 could increase plant tolerance of dehydration, salinity, ABA, ethylene, and salicylic acid (Ziaf et al., 2016). Furthermore, transformation of wild tomato ERD15 (SpERD15) into tobacco resulted in enhanced stress tolerance (Ziaf et al., 2011). Future work should be focused on the functional study on the litchi homologue ERD15-like (LcERD15-like). 


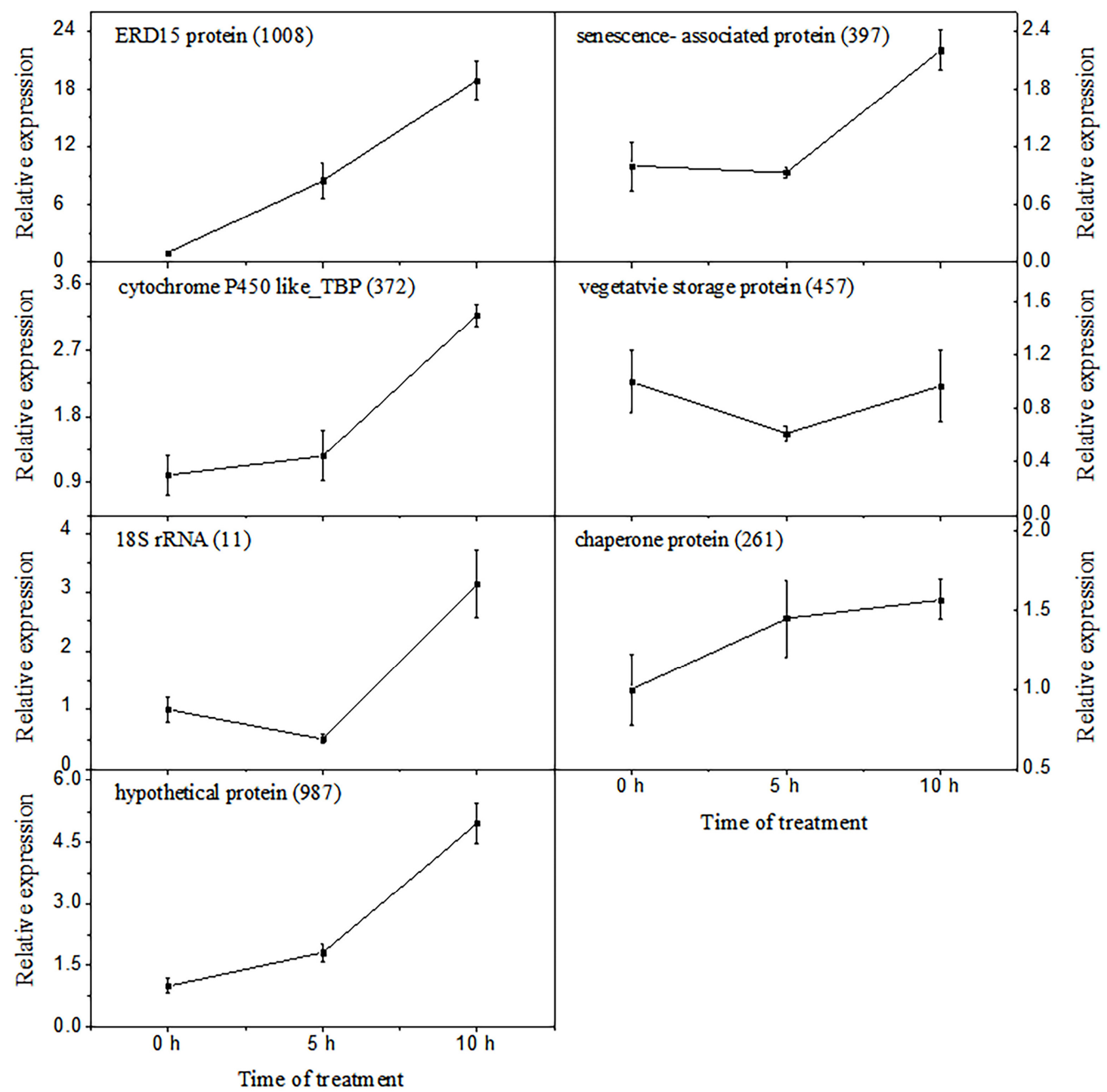

Fig. 5. Relative expression of 7 ESTs in the rudimentary leaves of 'Nuomici' litchi from 0 to $10 \mathrm{~h}$ of SNP treatment. The encoding proteins are indicated at the upper-left corner of the figures. The numbers marked in the brackets are the codes of the clones. Relative expression levels were calculated by qRT-PCR using the $2^{-\Delta \Delta C T}$ method with Actin as a reference gene. Data are means of 3 replicates and bars represent SD

\section{Conclusions}

We have constructed an SSH library for the NO-treated rudimentary leaves of litchi, and identified 16 ESTs associated with the NO-induced rudimentary leaf abortion. Most of them are functionally related with disease/defensive, protein destination and storage, and protein synthesis. The expression level of LcERD15-like increased from $0 \mathrm{~h}$ to $10 \mathrm{~h}$ of SNP treatment. LcERD15like may be an important $\mathrm{NO}$ responsive genes in litchi rudimentary leaves.

\section{Acknowledgements}

This work was supported by Ministry of Agriculture (grant number CARS-33-08), and the National Natural Science Foundation (grant number 31572080).

\section{References}

Alves MS, Fontes EPB, Fietto LG (2011a). Early responsive to dehydration 15 , a new transcription factor that integrates stress signaling pathways. PlantSignaling and Behavior 6(12):1993-1996. 
614

Alves MS, Reis PAB, Dadalto SP, Faria JAQA, Fontes EPB, Fietto LG (2011b). Anovel transcription factor, ERD15 (Early Responsive to Dehydration 15), connects endoplasmic reticulum stress with an osmotic stress-induced cell death signal. Journal of Biological Chemistry 286:20020-20030.

Beligni MV, Lamattina L (2001). Nitric oxide in plants: the history is just beginning. Plant, Cell and Environment 24(3):267-278.

Besson-Bard A, Astier J, Rasul S, Wawer I, Dubreuil-Maurizi C, Jeandroz S, Wendehenne D (2009). Current view of nitric oxide-responsive genes in plants. Plant Science 177(4):302-309.

Bevan M, Bancroft I, Bent E, Love K, Goodman H, Dean C, ... Chalwatzis $\mathrm{N}$ (1998). Analysis of $1.9 \mathrm{Mb}$ of contiguous sequence from chromosome 4 of Arabidopsisthaliana. Nature 391(6666):485-488.

Chen HB, Huang HB (2005). Low temperature requirements for floral induction in lychee. Acta Horticulture 665:195-202

Huang HB, Chen HB (2005). A phase approach towards floral formation in lychee. Acta Horticulturae 665:185-194.

Kariola T, Brader G, Helenius E, Li J, Heino P, Palva ET (2006). Early responsive to dehydration 15 , a negative regulator of abscisic acid responses in Arabidopsis. Plant Physiology 142(4):1559-1573.

Kiyosue T, Yamaguchi-Shinozaki K, Shinozaki K (1994). Cloning of cDNAs for genes that are early-responsive to dehydration stress (ERDs) in Arabidopsis thaliana L.: identification of three ERDs as HSP cognate genes. Plant Molecular Biology 25(5):791-798.

Lindermayr C, Saalbach G, Durner J (2005). Proteomic identification of $S$ nitrosylated proteins in Arabidopsis. Plant Physiology 137(3):921-930.

Liu WW, Chen HB, Lu XY, Rahman MJ, Zhong S, Zhou BY (2015). Identification of nitric oxide responsive genes in the floral buds of $L i t c h i$ chinensis. Biologia Plantarum 59(1): 115-122.

Liu WW, Kim HJ, Chen HB, Lu XY, Zhou BY (2013). Identification of MV-generated ROS responsive EST clones in floral buds of Litchi chinensis Sonn. Plant Cell Reports 32(9):1361-1372.

Livak KJ, Schmittgen TD (2001). Analysis of relative gene expression data using real-time quantitative PCR and the 2-DELTADELTACT method. Methods 25(4):402-408.

Lu X, Kim H, Zhong S, Chen H, Hu Z, Zhou B (2014). De novo transcriptome assembly for rudimentaryleaves in Litchichinesis Sonn. and identification of differentially expressed genes in response to reactive oxygen species. BMC Genomics 15:805.
Menzel CM, Simpson DR (1988). Effect of temperature on growth and flowering of litchi (Litchi chinensis Sonn.) cultivars. Journal of Horticultural Science 63(2):349-360.

Palavan-Unsal N, Arisan D (2009). Nitric oxide signalling in plants. The Botanical Review 75(2):203-229.

Polverari A, Molesini B, Pezzotti M, Buonaurio R, Marte M, Delledonne M (2003). Nitric oxide-mediated transcriptional changes in Arabidopsis thaliana. Molecular Plant Microbe Interactions 16(12):10941105.

Wang Y, Lin A, Loake GJ, Chu C (2013a). $\mathrm{H}_{2} \mathrm{O}_{2}$-induced leaf cell death and the crosstalk of reactive nitric/oxygen species. Journal of Integrative Plant Biology 55(3):202-208.

Wang Y, Loake GJ, Chu C (2013b). Cross-talk of nitric oxide and reactive oxygen species in plant programed cell death. Frontiers in Plant Science 4:314.

Yang HF, Lu XY, Chen HB, Wang C-C, Zhou B-Y (2017). Low temperature-induced leaf senescence and the expression of senescencerelated genes in the panicles of Litchi chinensis. Biologia Plantarum 61(2): 315-322.

Zhou B, Chen H,Huang X, LiN,HuZ, GaoZ,Lu Y (2008). Rudimentary leaf abortion with the development of panicle in litchi: changes in ultrastructure, antioxidant enzymes and phytohormones. Scientia Horticulturae 117(3):288-296.

Zhou B, Li N, Zhang Z, Huang X, Chen H, Hu Z, Pang X, Liu W, Lu Y (2012). Hydrogen peroxide and nitric oxide promote reproductive growth in Litchi chinensis. Biologia Plantarum 56(2):321-329.

Zhou J, Pesacreta TC, Brown RC (1999). RNA isolation without gel formation from oligosaccharide-rich onion epidermis. Plant Molecular Biology Reporter 17(4):397-407.

Ziaf K, Hussain Munis MFH, Samin G, Zhang X, Li J, Zhang J, Ye Z (2016). Characterization of ERD15 gene from cultivated tomato (Solanum lycopersicum). Pakistan Journal of Agricultural Sciences 53(1):27-33.

ZiafK, Loukehaich R, Gong P, Liu H, Han Q, Wang T,LiH, YeZ(2011). A multiple stress-responsive gene ERD15 from Solanum pennellii confers stress tolerance in tobacco. Plant and Cell Physiology 52(6):1055-1067. 